\title{
Kaynaştırma Öğrencilerinin Örgün Eğitimi Destekleme ve Yetiştirme Kurslarına İlişkin Görüşleri
}

\author{
Münevver SANCA \\ Millî Eğitim Bakanlığ1 \\ sancamunevver@gmail.com \\ ORCID ID: 0000-0002-8460-1967 \\ Hasan BAKIRCI \\ Van Yüzüncü Y1l Üniversitesi \\ hasanbakirci09@gmail.com \\ ORCID ID: 0000-0002-7142-5271
}

\begin{tabular}{lrr} 
Araştırma Makalesi & DOI: $10.31592 /$ aeusbed.740070 \\
\hline Geliş Tarihi: 20.05 .2020 & Revize Tarihi: 10.09 .2020 & Kabul Tarihi: 27.09 .2020
\end{tabular}

\section{Atıf Bilgisi}

Sanca, M. ve Bakırcı, H. (2020). Kaynaştırma öğrencilerinin örgün eğitimi destekleme ve yetiştirme kurslarına ilişkin görüşleri. Ahi Evran Üniversitesi Sosyal Bilimler Enstitüsü Dergisi, 6(3), 690-705.

\section{Öz}

Bu çalışma, Millî Eğitim Bakanlığı tarafından açılan Örgün Eğitimi Destekleme ve Yetiştirme Kursları'nı (DYK) kaynaştırma öğrencilerinin görüşleri çerçevesinde incelemek amacıyla yapılmıştır. Çalışmanın deseni, nitel araştırma yaklaşımlarından özel durum çalışması olarak belirlenmiştir. Veriler, araştırmacılar tarafından geliştirilen yarı yapılandırılmış mülakat formu ile 2019-2020 eğitim öğretim yılında toplanmıştır. Çalışmanın katılımcı grubunu Van ili Tuşba ilçesinde bulunan iki farklı ortaokulda, 2019-2020 eğitim öğretim yılında ortaokul 5., 6., 7., ve 8. sinıfta öğrenim gören dört k1z ve iki erkek öğrenci olmak üzere toplamda altı kaynaştırma öğrencisi oluşturmaktadır. Elde edilen verilerin çözümlenmesinde, betimsel ve içerik analizinden faydalanılmıştır. Bu çalışmanın bulgularında; Örgün Eğitimi Destekleme ve Yetiştirme Kursları hakkında kaynaştırma öğrencilerinin genel olarak olumlu görüşe sahip oldukları fakat uygulamanın bazı noktalarında eksikliklerin bulunmasından dolayı da olumsuz görüşe sahip oldukları tespit edilmiştir. Kaynaştırma öğrencileri, merkezi sınavlara hazırlanmalarına, akademik başarılarını artırmaya ve çalışma ortamı olușturmaya bu kursların yardımeı olduklarını belirtmișlerdir. Ayrıca kurslar konusunda kaynaștırma öğrencileri anlamadıkları konu ve soruların tekrarının yapılmasıyla vakitlerinin verimli geçmesini bir firsat olarak görmelerine karşın derslerde kullanılan yazılı materyallerde yazı puntolarının küçük olmasını eleştirmektedirler. Bunun yanı sıra öğretmenlerin sınıf içi etkinliklerinde bazı değişiklikler yaparak kaynaştırma öğrencilerinin de bu etkinliklere aktif olarak katılmalarını sağlamaları gerektiği sonucuna ulaşılmıştır. Araştırmada ortaya çıkan sonuçların başta Millî Eğitim Bakanlığı olmak üzere kurslar ile ilgili tüm paydaşlara yol göstereceği düşünülmektedir.

Anahtar Kelimeler: Kaynaştırma eğitimi, destekleme ve yetiştirme kursu, kaynaştırma öğrencisi.

\section{Inclusive Students' Opinions on Supporting Formal Education Courses}

\begin{abstract}
This study was carried out with the aim of examining the Formal Education Support and Training Courses opened by the Ministry of National Education from the perspective of inclusive students. The research employs case study and qualitative research approach. The data were collected in the 2019-2020 academic year and semi-structured interviews were used. The participants of this research are six inclusive students studying in two different secondary schools located in the province of Tusba in Van province. Four female and two male students studying in the $5^{\text {th }}, 6^{\text {th }}, 7^{\text {th }}$ and $8^{\text {th }}$ grades participated the research. Descriptive and Content analysis was used to analyse the data. The findings show that students had positive experiences and views about the supporting and training courses, but they also pointed out some of the problems. Students think that courses help them prepare for central exams, increase their academic success and create a working environment. Although they see the courses as an opportunity to catch up with the topics they have not fully understood, they mentioned that font sizes in materials are too small for them to read. In addition, it was concluded that teachers make some changes in classroom activities to ensure that inclusive students participate meaningfully. The results of this research has the potential to guide all stakeholders involved in preparation of these courses, especially the Ministry of National Education.
\end{abstract}

Keywords: Inclusive education, support and training course, inclusive student. 


\section{Giriș}

Antik çağdan günümüze eğitimin amaçları genel anlamda benzerlik göstermektedir. $\mathrm{Bu}$ bağlamda eğitimin amaçları; başarılı, üretken, kendine yeten, gelecekteki sosyal rollerini bilen, sosyal hayata uyumlu ve mutlu bireyler yetiştirmektir. Her birey özel ve değerli olmakla birlikte kendine özgü bir yetişme tarzına ve yeteneğe sahiptir. Aynı zamanda bireyler kendi yetenekleri ve farklılıkları doğrultusunda çevreye en iyi şekilde ayak uydurmaya çalışmayı hedeflemişlerdir. Tam da bu noktada eğitimin amaçlarıyla bu bireylerin amaçlarının aynı noktada kesişmesinin önemi ortaya çıktı̆̆ söylenebilir. Yani genel eğitim hizmetlerinin yanında bir de özel eğitim hizmetlerine yer verilmelidir (Millı̂ Eğitim Bakanlığı [MEB], 2010).

Özel eğitim hizmetleri yönetmeliğinde, “Özel eğitim ihtiyacı olan bireylerin eğitim ihtiyaçları, yeterlilikleri, ilgi ve yetenekleri doğrultusunda kapasitelerini en üst düzeyde kullanmalarl, meslek hayatına ve toplumsal yaşama hazırlanmalarını amaçlar" maddesi yer almaktadır (MEB, 2006, s.23). Türk Millî Eğitim Temel Kanunu'nun temel ilkelerinin sekizinci maddesinde, "Özel eğitime ve korunmaya muhtaç çocukları yetiştirmek için özel tedbirler alınır" ifadesi yer almaktadır (MEB, 1973, s. 5102). Anayasanın ikinci maddesi Türkiye Cumhuriyeti'nin sosyal ve hukuk devleti olduğunu belirtmektedir. Yani firsat ve imkân eşitliğine göre eğitimi planlamak, devletin vazgeçilmez görevlerindendir. Aynı şekilde Türk Millî Eğitim Temel Kanunu'nun genel amaçları üçüncü maddesinde yer alan "Illgi ve kabiliyetlerini gelişstirerek gerekli bilgi, beceri, davranışlar ve birlikte iş görme alışkanlığı kazandırmak suretiyle hayata hazırlamak ve onların, kendilerini mutlu kılacak bir meslek sahibi olmalarını sağlamak" ifadesi anayasanın ve özel eğitim hizmetleriyle ilgili açıkça belirtilen yönetmeliklerin ilgili maddeleriyle örtüşmektedir (MEB, 1973, s. 5102).

Özel gereksinimi olan bireyler; bedensel, zihinsel, duygusal ve sosyal özellikleri yönünden akranlarından farklı gereksinimleri olan bireylerdir (Kargın, 2004). Özel gereksinimi olan bireylerin, eğitimin çıktılarını tam olarak gösterebilmeleri için onların eğitim gereksinimlerinin iyi analiz edilip bu gereksinimlere en uygun ortamların hazırlanması gerekir. Özel gereksinimi olan bireylerin yararlanabilecekleri eğitim ortamları özel eğitim kurumları, okullardaki özel eğitim sınıfları ve normal eğitimin yapıldığı sınıflardır. Bu sınıflar bireylerin yetersizliğinin engele dönüşme ihtimalini ve yetersizliklerin olumsuz etkilerini en aza indirmeyi hedeflemektedir. Özel gereksinimi olan bireylerin normal sınıflarda akranlarıyla birlikte eğitim aldığı uygulama olan kaynaştırma eğitiminde, özel gereksinimli bireylerin akademik gelişimlerinin yanı sıra bilişsel, sosyal ve fiziksel gelişimleri de desteklenmektedir (Orakçı, Aktan, Toraman ve Çevik, 2016).

Kaynaştırma uygulamalarının farklı tanımlarının olduğu incelemeler sonucunda ortaya çıkmıştır. Bunlardan biri, özel gereksinimi olan öğrencilerin, akademik ve sosyal eğitim programlarının dikkatlice planlanarak ve değerlendirilerek, özel gereksinimi olmayan akranları ile birlikte eğitim almak üzere genel eğitim sınıflarına yerleştirilmeleri olarak tanımlanmasıdır (Lewis ve Doorlag, 1999). Kaynaştırma eğitimi, engelli öğrencilerin akademik, bilişsel, duygusal, bedensel ve en çok da sosyal becerilerini geliştirmelerini sağlayan bir eğitim türüdür (Türk, 2011). Bir başka deyişle kaynaştırma; özel eğitime ihtiyaç duyan bireylerin eğitimlerini, destek eğitim uygulamaları dâhilinde yetersizliği olmayan akranları ile beraber resmî ve özel; okul öncesi, ilköğretim, ortaöğretim ve yaygın eğitim kurumlarında sürdürmelerine yönelik her türlü özel eğitim uygulamalarının genel adıdır (Doğu, 2017).

Kaynaştırma uygulamalarının amacı, özel gereksinimi olan bireyleri normal olarak adlandırılan bir seviyeye getirmek değil, bu bireylerin var olan potansiyellerini maksimum seviyede ortaya çıkarmak ve bu bireylerin toplumda mutlu şekilde yaşayabilmesini sağlamaktır (MEB, 2019). Kaynaştırma uygulamalarının tarihsel gelişimine bakıldığında, farklı ülkelerde farklı şekillerde gelişme gösterdiği ve birçok ülkede yapılan yasal düzenlemeler sonucunda benimsendiği görülmektedir (Yazıcıŏlu, 2018). Amerika Birleşik Devletleri'nde (ABD) 1975 yılında kabul edilen Tüm Engelli Çocukların Eğitim Yasası, okul çağındaki engelli bireylerin uygun eğitim hizmetlerinden her alanda faydalanmasını hedefleyen bir yasadır (Sucuoğlu ve Kargın, 2010). Aynı şekilde Avustralya'da 1970'li yılların başında özel gereksinimi olan bireylerin normal eğitim ortamlarında 
eğitim alma hakkı hususundaki tartışmalar baş göstermiş ve 1992 yılında kabul edilen Engelli Ayrımcılı̆̆ 1 Yasası'yla bu tartışmaya nokta konulmuştur (Disability Discrimination Act, 1992). Kısacası 1970'li yıllarda ABD'de başlatılan kaynaştırma uygulamaları ilerleyen zamanlarda yaygınlaşmış ve çoğu ülkeyi etkisi altına almayı başarmıştır (Yazıcıoğlu, 2018).

Son dönemlerde kaynaştırma teriminin yerini bütünleştirme terimi almaya başladığı ve bütünleştirmenin kaynaştırmadan ayrıldığı bazı noktaların olduğu söylenebilir. Kaynaştırma, özel gereksinimi olan öğrencilerin eğitimini destek eğitim hizmetleri de sağlanarak normal gelişen akranları ile birlikte tam ya da yarı zamanlı olarak sürdürebilmeleri esasına dayanan özel eğitim uygulamalarıdır (MEB, 2006). Ayrıca kaynaştırmayı bütünleştirmeden ayıran temel nokta bütünleştirmede özel gereksinimi olan öğrencilerin genel eğitim sınıfına tam zamanlı olarak yerleştirilmesinin ve destek hizmetlerinin sınıf içinde sunulmasının amaçlanmasıdır (Gürgür, 2005). Tam zamanlı kaynaştırma özel eğitime ihtiyacı olan bireylerin öncelikle yetersizliği olmayan akranlarıyla birlikte aynı kurumda sürdürmeleri sağlanır (MEB, 2006). Öğrencilerin kaydı diğer akranlarıyla aynı sınıftadır ve tam gün boyunca aynı sınıfta eğitim alırlar. Ayrıca kaynaştırma öğrencilerine destek eğitim odasında çeşitli materyallerle desteklenmiş dersler verilir. Yarı zamanlı kaynaştırma uygulamaları öğrencilerin bazı derslere yetersizliği olmayan akranlarıla birlikte aynı sınıfta ya da ders dışı etkinliklere birlikte katılmaları yoluyla yapılır (MEB, 2006). Öğrencinin kaydı özel eğitim sınıfındadır ve kendilerine uygun Bireyselleştirilmiş Eğitim Programı (BEP) kapsamında ders alırlar.

Özel gereksinimi olan öğrencilerin var olan potansiyellerini en iyi şekilde ortaya çıkarmalarına ve topluma kazandırılmalarına yönelik uygulamalardan bir diğeri de destekleme ve yetiştirme kurslarına katılıyor olmalarıdır. 09.02.2017 tarihli Resmî Gazete'de yayımlanan 687 Sayılı Kanun Hükmünde Kararname ile 5580 sayılı Özel Öğretim Kurumları Kanunu’nda belirtilen "Öğrenci Etüt Eğitim Merkezleri” tanımı kaldırılmışıı. Dershane ve etüt merkezi ifadelerinin resmi olarak kaldırılması ile öğrencilerin okula takviye olarak yararlanabilecekleri tek kurum Millî Eğitim Bakanlığı Örgün Eğitimi Destekleme ve Yetiştirme Kursları (DYK) olmuştur. Böylece bakanlığın, DYK'ya düşen görevi artmıştır.

Millî Eğitim Bakanlığı Örgün Eğitimi Destekleme ve Yetiştirme Kursları'nda, öğrenciöğretmen etkileşimi ve öğrencilerin öğrenme eksikliklerini tamamlayıcı görev üstlenmektedir (MEB, 2020). Dershane ve etüt merkezlerin kapatılması sonucunda Millî Eğitim Bakanlığı örgün eğitimi destekleme ve yetiştirme kurslarına düşen görev artmıştır. Konuyla ilgili yapılan alan taramasında öğrenci ve öğretmenler eğitimi destekleme ve yetiştirme kurslarını genel değerlendirilmesine yönelik olumlu görüşe sahip olup bu kursların öğrenci motivasyonunu, ders performansını büyük ölçüde artırdığını düşündükleri görülmektedir (Nartgün ve Dilekçi, 2016). Öğretmenler destekleme ve yetiştirme kurslarının kendileri açısından avantajlarını en yoğun olarak ekonomik katkı, öğrenilmeyen, eksik konulara yoğunlaşma, kişisel ve mesleki gelişim olarak tanımlamışlardır (Sarıca, 2018). Bu kurslar, 2014 yılından itibaren ücretsiz olarak hizmet vermektedir. Kaynaştırma eğitimi alan özel gereksinimi olan öğrencilerin hafta içi derslerine ek olarak hafta sonu destekleme ve yetiştirme kurslarına katılabilmektedir.

Alanyazın incelemelerinde kaynaştırma uygulamalarıyla ilgili olarak birçok araştırmanın yapıldığını söylemek mümkündür. Fakat bu araştırmaların büyük bir kısmında kaynaştırma öğrencilerinin öğretmenlerinin, ebeveynlerinin ya da akranlarının görüşlerine yer verilmiştir. Yapılan bu çalışmalar incelendiğinde; sınıflarda öğrencilerin uygun davranışlarından çok uygun olmayan davranışlarına odaklanıldığı, uygun olmayan davranışlarının azaltılmasında pekiştirmeye dayalı uygulamalardan ziyade cezaya dayalı uygulamalara yer verildiği, öğrencilerin sosyal etkinliklere katılımlarının çoğu zaman teşvik edilmediği ve kaynaştırma uygulamalarında normal gelişen akranların desteğinin alınmadığı sonuçları karşımıza çıkmaktadır (Gül ve Vuran, 2015). Bu konuda başka bir çalışmada Atlan (2019), kaynaştırma öğrencilerinin yaşam doyumlarını ve benlik algılarını arttırmak için akademik becerilerin yanı sıra kendilerini ifade etme firsatının ve sosyal yaşantıların önemine vurgu yapmıştır. Deniz ve Çoban (2019) tarafından yapılan çalışmada öğretmenlerin, büyük bir kısmının kaynaştırma eğitimi ile ilgili yeterli eğitimi almadıkları, sınırlı düzeyde uygulama 
çalışması ve iş birliği yaptıkları ve kaynaştırma eğitimiyle ilgili yeterli fiziksel imkânlara sahip olmadıkları sonuçlarına ulaşılmıştır. Bu çalışma; özel eğitime ihtiyaç duyan ve kaynaştırma eğitimden bizzat yararlanan öğrencilerle ilgili yapılan çalışmaların sınırlı sayıda olması, kaynaştırma eğitimine ihtiyaç duyan öğrencilerinin sayısının son dönemlerde artmış olması ve yönetici ile öğretmenlerin kaynaştırma öğrencilerine nasıl davranacakları konusunda nitelikli bir hizmet içi eğitim almamış olmaları gibi sorunlara çözümler sunmak amacıyla yapılmıştır.

Kaynaştırma eğitimine devam eden ve kurslara katılan öğrencilerin aldıkları eğitim ve öğretim ile ilgili görüşleriyle karşılaştıkları sorunların belirlenmesi sonucunda kaynaştırma öğrencilerinin kurslar hakkındaki beklentileri ve önerilerinin ortaya çıkarılması hedeflenmektedir. Sonuç olarak bu beklentiler ve öneriler işığında kaynaştırma öğrencilerinin Örgün Eğitimi Destekleme ve Yetiştirme Kursları'ndan (DYK) en iyi şekilde faydalanmaları ve DYK'lerin amacının en iyi şekilde yerine getirilmesinin sağlanması hedeflenmektedir. Elde edilen bulgular kaynaştırmanın her alanda başarıya ulaşması, öğretmen ve yöneticilerin dikkat etmeleri gereken noktalarla ilgili yönlendirilmeleri gibi konularda alanyazına katkı sağlayacağı düşünülmektedir. Dolayısıyla bu çalışmanın amacı, Millî Eğitim Bakanlığı tarafından açılan Örgün Eğitimi Destekleme ve Yetiştirme Kursları'nı kaynaştırma öğrencilerinin görüşleri çerçevesinde incelemektir.

\section{Yöntem}

\section{Araştırmanın Deseni}

$\mathrm{Bu}$ çalışmada, nitel araştırma desenlerinden özel durum çalışması deseni kullanılmıştır. Nitel durum çalışmalarının en temel özelliği bir ya da birkaç durumun derinliğine araştırılmasıdır. Yani bir duruma ilişkin etkenler (ortam, bireyler, olaylar, süreçler, vb.) bütüncül bir yaklaşımla araştırılır ve ilgili durumu nasıl etkiledikleri ve ilgili durumdan nasıl etkilendikleri üzerine odaklanılır (Yıldırım ve Şimşek, 2018). Bu çalışmada özel durum çalışmasının tercih edilmesinde; kaynaştırma öğrencilerinin Örgün Eğitimi Destekleme ve Yetiştirme Kursları hakkında kaynaştırma öğrencilerinin görüşlerinin derinlemesine ve detaylı olarak ortaya çıkarılması etkili olmuştur.

\section{Katılımcilar}

$\mathrm{Bu}$ araştırmada, araştırma sonuçlarına en iyi şekilde ulaşmamızı sağlayan amaçlı örnekleme kullanılmıştır. Bunun için katılımcıların en az bir dönem boyunca Millî Eğitim Bakanlığı Örgün Eğitimi Destekleme ve Yetiştirme Kursları'na katılmış, kaynaştırma eğitiminden yararlanıyor ve ortaokula devam ediyor olması olmak üzere üç ölçüt belirlenmiştir. Ayrıca araştırmaya alınan katılımcıların sorulan soruları anlama, kendini iyi ifade etme olmak üzere iki ön koşul özelliğe de sahip olmaları beklenmiştir. Bu çalışmaya başlamadan önce gerekli veli ve yönetici izinleri alındıktan sonra bu şartları sağlayan öğrenciler belirlemek için çeşitli ortaokullar ile görüşülmüş; bu okullarda görev yapan psikolojik danışman ve rehber öğretmenler tarafından yapılan incelemeler sonucunda 15 öğrencinin istenen özellikleri sağladıkları belirlenmiştir. Öğretmenleri tarafindan önerilen bu öğrencilerle uygun bir zamanda tanışma toplantısı yapılıp bu öğrencilerin istenen ön koşullara sahip oldukları tespit edilmiştir. $\mathrm{Bu}$ tanışma toplantılarında öğrencilere günlük yaşamlarıyla ilgili bazı sorular yöneltilmiştir. Onbeş öğrenciden bir tanesinin tanışma esnasından konuşmak istememesi üzerine görüşmeye alınmamıştır. Ondört öğrencinin tamamının ön koşulları sağlaması üzerine görüşmeye alınmışlardır. Fakat bu öğrencilerden sekiz tanesinin görüşme sırasından farklı konulara değinmeleri ve bazı konularda konuşmak istememeleri üzerine görüşmeye sadece altı kişi aktif olarak katılmıştır. Araştırma 10-14 yaş aralığında bulunan altı öğrenciyle gerçekleşmiştir. Katılımcıların ikisi ortaokul altıncı sınıfa, ikisi ortaokul beşinci sınıfa ve son ikisi ortaokul sekizinci sınıfa devam etmektedir. Araştırmanın çalışma grubundan bulunan altı öğrenciyle yapılan görüşmeler sorunsuz bir şekilde sürdürülmüştür.

Özel gereksinimi olup kaynaştırma eğitiminden bizzat yararlanan ve Millî Eğitim Bakanlığı Örgün Eğitimi Destekleme ve Yetiştirme Kursları'na katılan öğrenciler, söz konusu kurslar hakkında en doğru bilgiyi verebilecek bireyler olarak görülmüş ve çalışmaya alınmışlardır. Bundan dolayı ilgili kaynaştırma öğrencilerinin kurslar hakkındaki görüşlerinin ortaya çıkarılması amaçlanmıştır. Yapılan 
görüşmelerde sorulan soruların anlaşılamaması, öğrencilerin kendilerini ifade edememesi ve soruların yanıtlanma oranının düşük olması bir sınırlılık oluşturabileceği fakat soruları anlama ve en uygun cevapları verebilecek gönüllü ve istekli öğrencilerin katılımcı olarak seçilmesi bu sınırlılığı olabildiğince azaltabileceği düşünülmüştür. Katılımcılar, $M_{1}, M_{2}, M_{3}, M_{4} M_{5}$ ve $M_{6}$ şeklinde kodlanmıştır. Katılımcıların özellikleri Tablo 1'de verilmiştir.

Tablo 1

Katılımci Özellikleri

\begin{tabular}{ccccc}
\hline Katılımcılar & Yaş & Özel Alan Tanısı & $\begin{array}{c}\text { Kaynaştırma Eğitimi } \\
\text { Almaya Başladığ1 Kademe }\end{array}$ & $\begin{array}{c}\text { DYK' ye } \\
\text { Katılma Y1lı }\end{array}$ \\
\hline $\mathrm{M}_{1}$ & 10 & Özel öğrenme güçlüğ̈̈ & 4.sınıftan itibaren & 1 \\
\hline $\mathrm{M}_{2}$ & 10 & Özel öğrenme güçlüğü & 4.sınıftan itibaren & 1 \\
\hline $\mathrm{M}_{3}$ & 10 & Özel öğrenme güçlüğ̈̈ & 4.sınıftan itibaren & 1 \\
\hline $\mathrm{M}_{4}$ & 12 & Özel öğrenme güçlüğü & 5.sınıftan itibaren & 2 \\
\hline $\mathrm{M}_{5}$ & 14 & Özel öğrenme güçlüğü & 5.sınıftan itibaren & 2 \\
\hline $\mathrm{M}_{6}$ & 14 & Özel öğrenme güçlüğ̈̈ & 4.sınıftan itibaren & 3 \\
\hline
\end{tabular}

\section{Veri Toplama Aracı ve Veri Toplama Çalışmaları}

Araştırmaya başlamadan önce alanyazın taraması yapılmış ve araştırmanın kuramsal boyutunu oluşturmak için araştırma konusunda alanyazındaki eksiklikler tespit edilmiştir. Daha sonra araştırmacı tarafından geliştirilen ve sekiz sorudan oluşan Yarı Yapılandırılmış Görüşme Formu hazırlanmıştır. Alanyazında özel gereksinimi olan kaynaştırma öğrencilerinin görüşlerini içeren yeterli çalışma olmadığından araştırmacı görüşme sorularını, kaynaştırma eğitiminde temel sorun olarak gördüğü bazı ögeleri dikkate alarak ve deneyimlerine dayanarak hazırlamıştır. Araştırmacı hazırlamış olduğu soruları çeşitli ortaokullarda görev yapan beş okul psikolojik danışman ve rehberlik öğretmenine, yeterli sayıda yüksek lisans öğrencisine ve çalışmanın yürütüldüğü ilçede bulunan uzmanlara inceletirilmiş; onların görüş ve önerilerini dikkate alarak sorulara son şeklini vermiştir. Böylece araştırma sorularının geçerliliği saptanmış ve toplam beş soru belirlenmiştir. Sorular öğrencilerin anlayabileceği türden basit bir şekilde hazırlanmıştır. Yarı Yapılandırılmış Görüşme Formu Ek-1'de verilmiştir.

Araştırmacı görüşmeye başlamadan önce öğrencilere; okul, arkadaşları, kendisi ve destekleme ve yetiştirme kursları ile ilgili sorular soracağını belirtmiş ve soruların doğru cevaplarının olmadığını öğrencilere hatırlatarak kendilerini sınavda hissetmemelerini sağlamıştır. Ayrıca yeterli zamanın olduğunu onlara söyleyerek anlamadıkları soruları tekrardan sorabileceklerini söylemiştir. Sorulara tekrardan göz atmalarına da firsat tanınmıştır. Görüşme esnasında ses kaydı yapacağını ve kişisel bilgilerinin bu ses kaydında yer almayacağı hatırlatılmıştır. Son olarak ise katılımcılara "Görüşsme öncesi anlamadığınız bir yer ve sormak istediğiniz soru var mı?" sorusu yöneltilerek katılımcılar hazır olduklarını belirttiklerinde görüşmeye başlanmıştır.

Görüşmelerin yapılması için katılımcıların gönüllü olmalarına dikkat edilmiş ve gerekli yöneticiler ile ailelerinden gerekli izinler alınmıştır. Görüşmeler esnasında ses kayıt cihazı ve görüşme sorularının yer aldığ1 görüşme formu kullanılmıştır. Görüşmeler 15-20 dakika arasında sürmüştür. Araştırmacı görüşmeler esnasında gerektiği zaman var olan soruların alternatif sorularını katılımcılara yöneltmiş ve önem arz eden cevapları not etmiştir.

\section{Geçerlik ve Güvenirlik Çalışmaları}

Yarı Yapılandırılış Görüşme Formu'nun hazırlanma sürecinde geçerlik ve güvenirlik çalışmaları da yapılmıştır. Bu bağlamda, öncelikle özel gereksinim olan bireylerin örgün eğitim konusundaki görüşleri ile ilgili alan yazın taraması yapılmış ve daha sonra Örgün Eğitimi Destekleme ve Yetiştirme Kursları Yönergesi, kurslara ait kılavuzlar incelenmiştir. Elde edilen bilgiler doğrultusunda açık uçlu sorular hazırlanmıştır. 
İç geçerliği sağlayabilmek için, hazırlanan sorular ile ilgili olarak, iki doktora öğrencisinin, alanında uzman bir akademisyenin ve alanında uzman üç okul psikolojik danışmanının ve altı yüksek lisans öğrencisinin görüşleri alınmıştır. Alınan görüşler doğrultusunda gerekli düzenleme ve düzeltmeler yapılmıştır. En başta sekiz soru olarak hazırlanmış görüşme formu, uzman kişilerin ortak görüşleri doğrultusunda beş soru olarak revize edilmiştir.

Kapsam geçerliliğinin sağlanması için uzman görüşleri alınarak hazırlanan görüşme formu ilgili öğrencilerin bulunduğu okullardaki okul psikolojik danışman ve rehberlik öğretmenlerinin görüşleri de alınarak son şekli verilmiş ve araştırma grubu dışında yer alan toplamda beş öğrenciye de ön uygulama yapılmıştır. Ön uygulama sonuçlarına göre, hazırlanan soruların katılımcılar tarafından anlaşılır ve uygulanabilir olduğu belirlenmiştir. Ayrıca görüşme formunda bulunan sorulara öğrencilerin vermiş olduğu cevaplar değiştirilmeden birinci ağızla kaydedilmiş ve bu formlar öğrencilere tekrar okutularak sorulara verilen cevapların doğruluğu teyit edilmiştir.

\section{Verilerin Analizi}

Yarı yapılandırılmış görüşme ile elde edilen verilerin analizinde, betimsel ve içerik analiz tekniği kullanılmıştır. Görüşmeler, ses kayıt cihazı yardımıyla kayıt altına alınmıştır. Kayıt altına alınan görüsşme verileri, araştırmacılar tarafından düz yazıya dönüştürülmüştür. Araştırmacılar tarafından düz yazıya aktarılan veriler incelenmiştir. Bu inceleme sonucunda çalışma soruları kapsamı dışından olan veriler, veri setinden çıkarılmıştır. Çalışma kapsamı dışındaki verilerden arındırılmış veri setinin öğrenciler tarafından incelemeleri sağlanmıştır. Bu inceleme aracılı̆̆ıyla öğrencilerin görüşme esnasında vermiş oldukları cevapları tekrar gözden geçirmeleri istenmiştir. Bunun yanında veri setine eklemek ya da çıkarmak istedikleri cevapları belirtmeleri arzulanmıştır (Yıldırım ve Şimşek, 2018). Yapılan bu işlemler, aslında verilerin güvenirliği sağlamaya yönelik işlemler olduğu söylenebilir. Veri setinin son hali, üç fen eğitimcisi tarafından farklı zamanlardan incelenmiştir. Bu inceleme sonucunda her bir fen eğitimcisi bu veri setinde tema ve kodlar oluşturmuştur. Daha sonra üç fen eğitimcisi bir araya gelerek yapmış oldukları analizi değerlendirmişlerdir. Bu değerlendirmede fen eğitimciler, elde edilen verilerde görüş birliğine varılamayan tema ve kodlar üzerinde tartışma yaparak uzlaşmaya gitmişlerdir (Denzin ve Lincoln, 1994). Böylece üç fen eğitimcisi, çalışmanın amacına bağlı kalarak kod ve temaların son halini vermişlerdir. Üç fen eğitimcisi, tema ve kodların tutarlılı̆̆ını belirlemek için Miles ve Huberman (1994) tarafından ortaya atılan formülden yararlanmışlardır. Bu formüle göre üç fen eğitimcisinin yapmış oldukları veri analizinin uyuşma oranı \%81 olarak hesaplanmıştır. Bu oran, verilerin güvenilir bir şekilde analiz edildiğini ortaya koymaktadır (Miles ve Huberman, 1994). İçerik analiz ile oluşturulan tema ve kodları desteklemek için öğrenci cevaplarından doğrudan alıntı yapılmıştır. Son olarak katılımcıların cevaplarından oluşturulan tema ve kodlar tablo şekline getirilerek verilerin analizi sonlandırılmıştır.

\section{Etik Kurul Kararı}

Van Yüzüncü Y1l Üniversitesi Sosyal ve Beşeri Bilimleri Etik Kurulu (14/05/2020 tarih ve 2020/03-07 sayı) tarafından "Kaynaştırma Öğrencilerinin Örgün Eğitimi Destekleme ve Yetiştirme Kurslarına Illişkin Görüşleri" adlı çalışmasında kullanılacak olan araçlar incelenmiş olup, söz konusu araçların ilgili kişilere uygulanmasında Sosyal ve Beşeri Etik Kuralları ve İlkeleri çerçevesinde herhangi bir sakınca olmadığına karar verilmiştir.

\section{Bulgular}

$\mathrm{Bu}$ çalışmaya katılan kaynaştırma öğrencilerinin mülakatta yer alan sorulara vermiş olduğu cevaplar, soru bazında incelenerek okuyuculara sunulmuştur. Öğrencilerin mülakatın birinci sorusuna verdiği cevaplardan yola çıkılarak oluşturulan tema ve kodlar Tablo 2'de verilmiştir. 
Tablo 2

Kaynaştırma Öğrencilerinin "DYK Hakkında Kısaca Bilgi Verebilir Misiniz?” Sorusuna Vermiş Oldukları Cevaplardan Oluşturulan Tema ve Kodlar

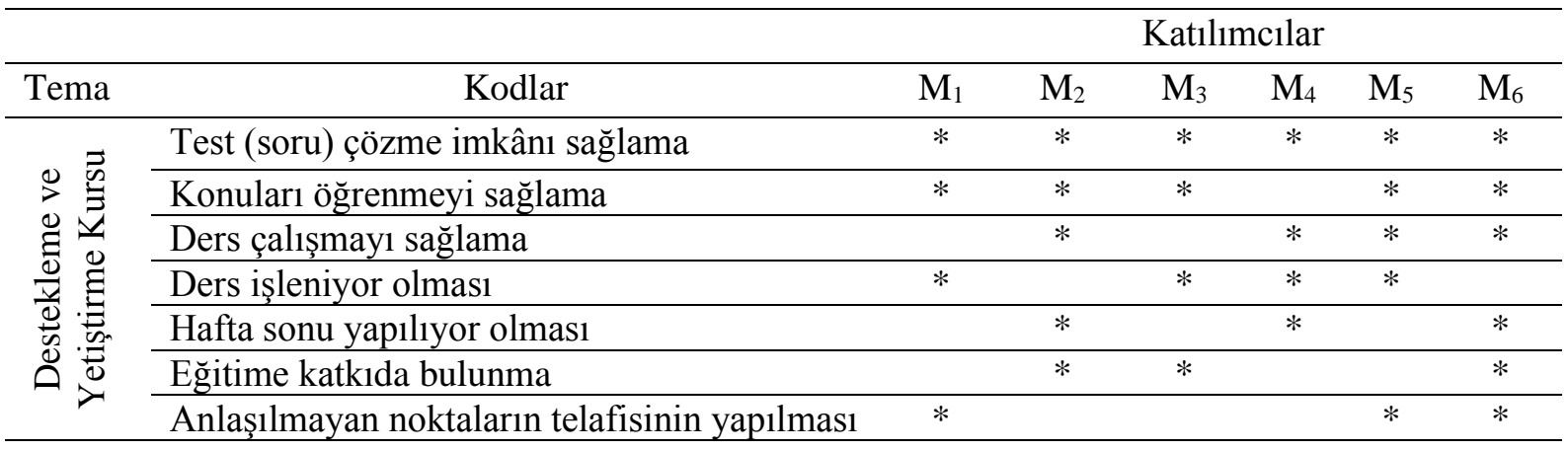

Tablo 2 incelendiğinde, Örgün Eğitimi Destekleme ve Yetiştirme Kursları'nın kaynaştırma öğrencileri tarafından farklı şekillerde tanımlandığı görülmektedir. Söz konusu kurslar hakkında öğrencilerden $\mathrm{M}_{6}$; "Kurslara geldiğim zaman genellikle konuları daha iyi öğreniyorum. Konu tekrarı yaparak daha fazla soru çözmemi sağllyor. Ayrıca anlamadığım yerleri hocalarıma sorma imkânım oluyor." şeklinde görüş bildirerek kursların normal zamanda işlenen konularla ilgili anlaşılmayan noktaların telafi edilmesi imkânını sağladığına vurgu yapılmıştır. Bunun yanı sıra $\mathrm{M}_{5}$; "Kurslarda ders çalışıyoruz, soru çözüyoruz, hocalarımızın anlattıklarını dinliyoruz, hocalarımızın dağıttı̆̆ testleri veya akıllı tahtadaki (etkileşimli tahta) testleri çözüyoruz." şeklinde görüş bildirerek bu kursların okullarda akademik başarıyı artırmak için birtakım çalışmalar içerdiğini ifade etmiştir.

Kaynaştırma öğrencilerinin mülakatın ikinci sorusuna verdikleri cevaplardan elde edilen tema ve kodlar Tablo 3' te verilmiştir.

Tablo 3

Kaynaştırma Öğrencilerinin “DYK'ya Katılma Sebepleriniz Nelerdir?” Sorusuna Vermiş Oldukları Cevaplardan Oluşturulan Tema ve Kodlar

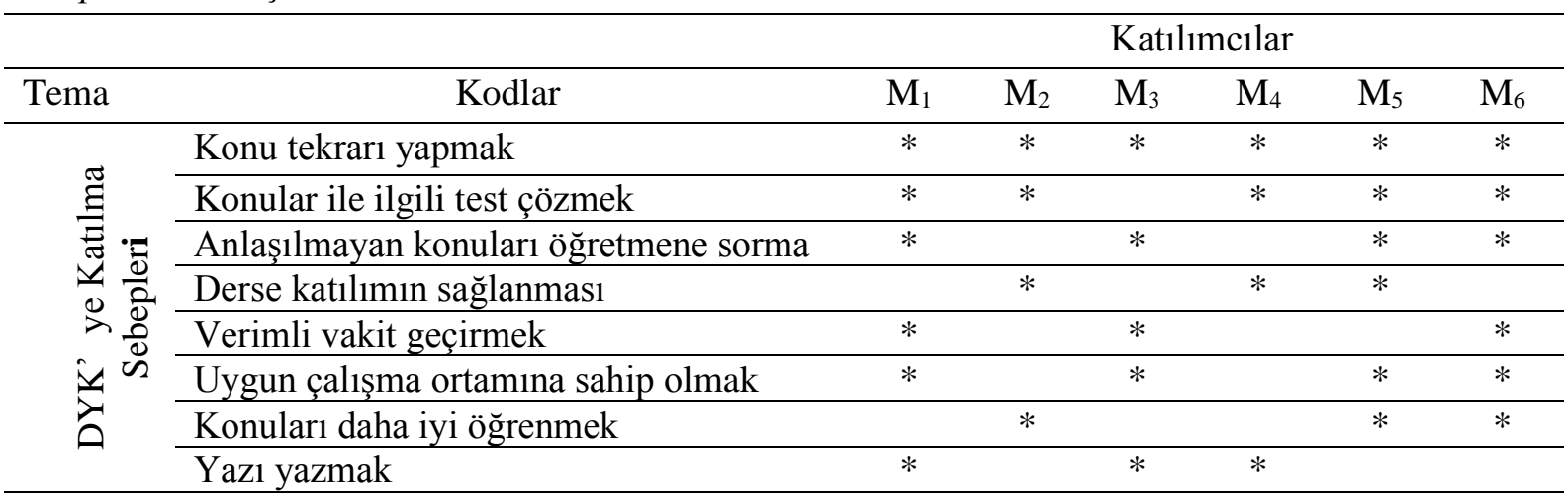

Tablo 3 incelendiğinde, katılımcılar "DYK' ye Katılma Sebepleri” teması altında; konu tekrarı yapmak, test çözmek, anlaşılmayan konuları hocalara sormak, verimli vakit geçirmek şeklinde görüş beyan etmişlerdir. $\mathrm{Bu}$ konuda $\mathrm{M}_{1}$ katılımcısi; "Kurslar verimli vakit geçirmemi sağllyor." ve $\mathrm{M}_{2}$ katılımcıs1; "Kurslarda soru çözüyoruz. Fakat sadece soru çözmek için değil aynı zamanda okumamı, yazmamı ve matematiğimi daha iyi gelişstirdiği için kurslara katıllyorum." şeklinde görüş beyan ederek kursların sadece merkezi sınavlara yönelik olmayıp öğrencilerin bazı eksikliklerinin de telafi edildiğini göstermektedir. Bunun yanı sıra katılımcıların tamamı, kurslara konu tekrarı yapıldığı için katıldığına dair görüş bildirmiştir. Ayrıca $\mathrm{M}_{6}$ öğrencisi; "Evde çalışma masam ve kendime ait bir odam olmadiğı için ders çalışamıyorum. Evde bulamadığım çalışma ortamını kurslarda buluyorum. Bu yüzden kurslara gelmem gerekiyor. Ayrıca evde çalışamadığım zaman kurslarda çalışlyorum." şeklinde görüş bildirerek kursların öğrencilere aynı zamanda uygun bir çalışma ortamı sağladığını da vurgulamıştır. 
Kaynaştırma öğrencilerinin mülakatın üçüncü sorusuna verdikleri cevaplardan elde edilen tema ve kodlar Tablo 4'te verilmiştir.

Tablo 4

Kaynaştırma Öğrencilerinin “DYK'da Katıldı̆̆ınız Derslerin Size Să̆ladı̆̆ Katkılar Nelerdir?” Sorusuna Vermiş Oldukları Cevaplardan Oluşturulan Tema ve Kodlar

\begin{tabular}{|c|c|c|c|c|c|c|c|}
\hline \multirow[b]{2}{*}{ Tema } & \multirow[b]{2}{*}{ Kodlar } & \multicolumn{6}{|c|}{ Katılimcilar } \\
\hline & & $\mathrm{M}_{1}$ & $\mathrm{M}_{2}$ & $\mathrm{M}_{3}$ & $\mathrm{M}_{4}$ & $\mathrm{M}_{5}$ & $\mathrm{M}_{6}$ \\
\hline \multirow{7}{*}{ 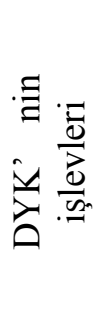 } & Anlaşılamayan yerlerin hocalara sorulması & $*$ & $*$ & $*$ & $*$ & $*$ & $*$ \\
\hline & Etkileşimli tahtadan soru çözme & $*$ & $*$ & $*$ & $*$ & $*$ & $*$ \\
\hline & Ders çalışma imkânı sağlama & $*$ & $*$ & & $*$ & $*$ & \\
\hline & Test(soru) çözme & & $*$ & & $*$ & $*$ & $*$ \\
\hline & Konu tekrar1 yap1lması & $*$ & & $*$ & $*$ & & $*$ \\
\hline & Yeni bilgiler öğrenmeyi sağlama & & $*$ & $*$ & $*$ & & $*$ \\
\hline & Sınavlara hazırlığı sağlama & $*$ & & * & & $*$ & $*$ \\
\hline
\end{tabular}

Tablo 4 incelendiğinde, katılımcılar "DYK' nin İşlevleri”" teması altında; anlaşılamayan yerlerin hocalara sorulması, etkileşimli tahtadan soru çözme, ders çalışma imkânı sağlama, konu tekrar1 yapılması şeklinde görüş beyan etmişlerdir. Konuyla ilgili $\mathrm{M}_{2}$ öğrencisi; "Anlamadiğım bir konu olduğumda ögretmenime soruyorum ve bana bireysel olarak anlatiyor. Ayrıca sinıf mevcutları diğer günlere göre daha düşük olduğu için daha verimli ders işleyebiliyoruz." şeklinde görüş beyan etmiştir. Aynı soruya $\mathrm{M}_{6}$ öğrencisi; "Kurslarda bize kaynak kitap desteği sağlanıyor ve bazı dersleri oyun oynayarak işliyoruz. Bu da dersleri sevmemi sağllyor." ş̧eklinde görüş beyan etmiştir. Öğrencilerden $\mathrm{M}_{1}$; “Etkileşimli tahtadan soru çözüyoruz veya farklı videolar izliyoruz." şeklinde görüş beyan etmiştir. Öğrencilerden $\mathrm{M}_{4}$; Kurslar yeni şeyler ögrenmemi ve konuların aklımda daha uzun süre kalmasını sağllyor. ” şeklinde görüş beyan etmiştir.

Kaynaştırma öğrencilerinin mülakatın dördüncü sorusuna verdikleri cevaplardan elde edilen tema ve kodlar Tablo 5'te verilmiştir.

Tablo 5

Kaynaştırma Öğrencilerinin “DYK’nın Size Göre Sinırlılıkları Nelerdir?” Sorusuna Vermiş Oldukları Cevaplardan Oluşturulan Tema ve Kodlar

\begin{tabular}{|c|c|c|c|c|c|c|c|}
\hline \multirow[b]{2}{*}{ Tema } & \multirow[b]{2}{*}{ Kodlar } & \multicolumn{6}{|c|}{ Katılımcilar } \\
\hline & & $\mathrm{M}_{1}$ & $\mathrm{M}_{2}$ & $\mathrm{M}_{3}$ & $\mathrm{M}_{4}$ & $\mathrm{M}_{5}$ & $\mathrm{M}_{6}$ \\
\hline \multirow{6}{*}{ 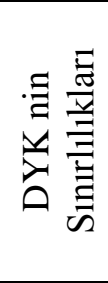 } & Teneffüslerin kısa olması & $*$ & $*$ & $*$ & $*$ & $*$ & $*$ \\
\hline & Ak1llı tahtanın aktif kullanılmaması & $*$ & $*$ & & $*$ & $*$ & $*$ \\
\hline & Ders materyallerinin küçük yazılı olmas1 & $*$ & & $*$ & $*$ & $*$ & \\
\hline & Fazla yazı yazılması & $*$ & $*$ & & $*$ & $*$ & \\
\hline & Sınıf mevcutlarının kalabalık olması & & & $*$ & & $*$ & $*$ \\
\hline & Deney yap1lmamas1 & & $*$ & & $*$ & & \\
\hline
\end{tabular}

Tablo 5 incelendiğinde katılımcılar, "DYK' nin Sinırlılıklarl” teması altında; teneffüslerin kısa olması, akıllı tahtanın aktif kullanılmaması, ders materyallerinin küçük yazılı olması ve fazla yazı yazılması şeklinde görüş beyan etmişlerdir. Bu konuyla ilgili $\mathrm{M}_{6}$ öğrencisi; "Yapamadiğım her sorumu ögretmenime soramıyorum. Ĕger bireysel ders alsaydım her sorumu sorabilirdim ve hocalartm bana daha fazla vakit ayırabilirdi. Söz hakkı istediğimde bazen bana sıra gelmiyor. Çünkü sinıf mevcutları kalabalık oluyor. Ayrıca bazı ögretmenler bir üniteyi tam olarak biz anlamadan diğer ünitelere geçiyor." şeklinde görüş beyan etmiştir. Aynı soruya $\mathrm{M}_{5}$ katılımcıs1; "Etkileşimli tahta ders işlenmese daha iyi olurdu. Çünkü ben akıllı tahtadan bir şeyleri izleyerek anlayamıyorum. Yazı yazmadan sadece akall tahtadan ders işlendiğinde anlatılanları takip edemiyorum." şseklinde görüş beyan etmiştir. $\mathrm{M}_{3}$ öğrencisi; "Tahtaya yazılan yazıların küçük olduğunda ve arka sıralarda oturduğumda 
dersleri takip edemiyorum şeklinde görüş beyan etmiştir.” $\mathrm{M}_{4}$ öğrencisi; "Bazen fazla yazı yazıyoruz ve benim ellerim çok ağrıyor. "ş̧eklinde görüş beyan etmiştir.

Kaynaştırma öğrencilerinin mülakatın beşinci sorusuna verdikleri cevaplardan elde edilen tema ve kodlar Tablo 6'da verilmiştir.

Tablo 6

Kaynaştırma Öğrencilerinin "DYK’nın Geliştirebilmesi ve Kalitesinin Artırılması İçin Neler Yapılmasını İstersiniz?” Sorusuna Vermiş̧ Oldukları Cevaplardan Oluşturulan Tema ve Kodlar

\begin{tabular}{|c|c|c|c|c|c|c|c|}
\hline \multirow[b]{2}{*}{ Tema } & \multirow[b]{2}{*}{ Kodlar } & \multicolumn{6}{|c|}{ Kat1lımcilar } \\
\hline & & $\mathrm{M}_{1}$ & $\mathrm{M}_{2}$ & $\mathrm{M}_{3}$ & $\mathrm{M}_{4}$ & $\mathrm{M}_{5}$ & $\mathrm{M}_{6}$ \\
\hline \multirow{8}{*}{ 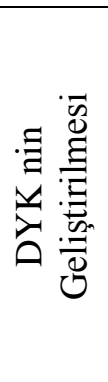 } & Daha fazla deney yapılmalı & & $*$ & $*$ & $*$ & $*$ & $*$ \\
\hline & Sinıf mevcutları daha az olmalı & & $*$ & & $*$ & $*$ & $*$ \\
\hline & Sinıfta önde olan bir sırada oturmak & $*$ & $*$ & $*$ & & $*$ & \\
\hline & Tahtadaki yazılar büyük puntoyla yazılmalı & $*$ & & $*$ & & $*$ & \\
\hline & Teneffüs saatleri daha uzun olmalı & $*$ & & $*$ & $*$ & & $*$ \\
\hline & Kursların başlangıç saatleri ileriye alınmalı & & & $*$ & & $*$ & $*$ \\
\hline & Etkileşimli tahta daha aktif kullanılmalı & & $*$ & & $*$ & & $*$ \\
\hline & Ders anlatılırken daha yavaş anlatılmalı & $*$ & & $*$ & * & & $*$ \\
\hline
\end{tabular}

Tablo 6 incelendiğinde katılımcılar, "DYK' nin Geliștirilmesi" teması altında; daha fazla deney yapılmalı, sınıf mevcutları az olmalı, sınıfta ön sıralarda oturmak ve tahtadaki yazılar büyük puntoyla yazılmalı ve teneffüsler daha uzun olmalı şeklinde görüş beyan etmişlerdir. Öğrencilerden $\mathrm{M}_{6 ;}$ "Akull tahtaları daha aktif kullanmak istiyorum, okula yürüyerek geliyorum ve evim okuluma uzak bir mesafede olduğu için yoruluyorum. Okul servisi ayarlanabilir veya kursların başlangıç saati biraz ileriye alınabilir. Ayrıca konular işlenirken biraz daha yavaş gidilebilir ve daha fazla soru çözülebilir." şeklinde görüş beyan etmiştir. Aynı soruya $\mathrm{M}_{4}$ ve $\mathrm{M}_{5}$ öğrencileri; "Derslerde daha fazla deney yapılabilir." ş̧eklinde görüş beyan etmişlerdir. Aynı şekilde $\mathrm{M}_{2}$ ve $\mathrm{M}_{3}$ öğrencileri; "Sinıfta ön stralarda oturmak derse daha fazla odaklanmamı sağllyor." şeklinde görüş beyan etmişlerdir. Konuyla ilgili $\mathrm{M}_{1}$ öğrencisi, "Sınıf mevcutları daha az olmalıdır." şeklinde görüş beyan etmiştir. Ayrıca $\mathrm{M}_{4}$ öğrencisi; "Dersler işlenirken biraz ders işlenmeliyiz ve biraz da oyun oynamallyız." şeklinde görüş beyan etmiştir.

\section{Sonuç, Tartışma ve Öneriler}

Kaynaştırma öğrencilerinin Örgün Eğitimi Destekleme ve Yetiştirme Kursları hakkında görüşlerinin araştırıldığı bu çalışmada elde edilen bulgular alanyazın ışığında tartışılarak aşağıda sunulmuştur.

$\mathrm{Bu}$ çalışmaya katılan kaynaştırma öğrencileri, destekleme ve yetiştirme kurslarıyla ilgili çoğunlukla olumlu görüş belirtmekle birlikte kursların bazı yönlerinin geliştirilmesi gerektiğini ifade etmişlerdir. Söz konusu kurslar, öğrenci ve kursiyerleri örgün eğitim müfredatındaki derslerle sınırlı olarak desteklemek ve yetiştirmek amacıyla açılmıştır (MEB, 2020). Bu bakımdan MEB'in bu kursları açmasındaki amaç ile kaynaştırma öğrencilerinin bu kurslara katılma amaçlarının birbiri ile genel olarak örtüştügü sonucuna varılmaktadır. Fakat kaynaştırma öğrencilerinin bu kurslara katılma amac1 sadece merkezi sınavlara (Örneğin, Liselere Geçiş Sınavı ve Parasız Yatılı Bursluluk Sınavı vb.) hazırlanmak değil, çeşitli etkinliklere katılmak, zamanını verimli geçirmek, daha fazla soru çözebilmek, evde bulamadığı çalışma ortamını telafi edebilmek ve okuldaki akademik başarısını artırmak olduğu tespit edilmiştir.

Katılımcılar, sınıfta etkileşimli tahta ve yazılı öğretim materyallari kullanılırken kaynaştırma öğrencilerinin gelişim düzeylerinin öğretmenler tarafından dikkate alınmadığını belirtmişlerdir (Bkz. Tablo 5). Bu konuda $\mathrm{M}_{6}$ katılımc1; "Sinıf mevcudumuz genelde 20 kişiden fazla olduğu için bize 
bireysel vakit ayrılmıyor ve derslerde kullanılan ögretim materyalleri diğer öğrencilere göre yapıldı̆̆ için dersi takip etmekte zorlaniyorum." şeklinde görüşünü dile getirmiştir. Aynı durum $\mathrm{M}_{3}$ katılımcısı tarafindan "Derslerde genelde arka siralarda oturmak zorunda kallyorum ve tahtayl görmekte zorlanıyorum, dersleri takip edemediğim için dikkatim dağılıyor." şeklinde ifade edilmiştir. Örneğin, derslerde dağıtılan yazılı materyaller (test vb.) her bir kaynaştırma öğrencisinin görebileceği ve şekilleri iyi ayırt edebileceği büyüklükte olmadığı çalışmaya katılan öğrenciler tarafından doğrulanmıştır. Ayrıca etkileşimli tahtanın aktif kullanılmaması ve kullanılırken de yazı veya görsel büyüklüğ̈nün kaynaştırma öğrencilerine hitap etmeyen bir düzeyde olduğu katılımcılar tarafindan ifade edilen görüşler arasındadır.

Çalışmaya katılan kaynaştırma öğrencileri destekleme ve yetiştirme kurslarında etkileşimli tahtanın veya birden çok duyuya hitap edebilen materyallerin aktif kullanılmamasından ve öğretmenlerin genel olarak tahtada düz anlatım tekniğini kullanarak ders anlattıklarını dile getirmişlerdir. Ünsal ve Korkmaz (2016) yaptıkları çalışmada öğretmenlerin kurslarda en çok anlatım ve soru cevap yöntemini tercih ettiklerini ortaya çıkarmışlardır. Benzer şekilde Göksu ve Gülcü (2016) destekleme ve yetiştirme kurslarında öğretmenlerin sıkça soru çözme yöntemini kullanarak soru çözdüğünü ifade etmişlerdir. Gelişim ve öğrenme özellikleri farklı olan, tek düze öğretimden eşit oranda istifade edemeyen kaynaştırma öğrencileri için düz anlatım yönteminin yanı sıra keşfe dayalı öğrenme, işbirlikçi öğrenme gibi farklı öğretim teknikleri de kullanılmalıdır (Prater, 2006).

Sınıfında kaynaştırma öğrencisi bulunan öğretmenlerin, evrensel tasarım ilkelerine dikkat etmeleri genel olarak öneriler arasındadır. Evrensel tasarımın eşit kullanım ilkesi, sınıf materyallerini farklı öğrenme gereksinimleri ve tarzları için ulaşılabilir kılmayı; kullanımda esneklik ilkesi, çeşitli öğretim yöntemlerini kullanmayı; basit ve sezgisel olma ilkesi, açık bir şekilde öğretim yapmayı; destekleme ve teşvik etme ilkesi öğretim ortamı ilkesi tüm öğrencileri derse katılımları için cesaretlendirmeyi kapsamaktadır (Pliner ve Johnson, 2004). Bu bağlamda evrensel tasarım ilkeleri, tüm öğrencilere eşit şartlar ve öğrenme ortamları sağlayacak, onların öğrenme ihtiyaçlarına hitap edecek öğretimlerin olacağı düşünülmektedir. Evans, Williams, King ve Metcalf (2010) yaptıkları çalışmalarında, öğretmenlerin farklılaştırılmış öğretim ve öğrenme için evrensel tasarımda sözü edilen farklı yöntemleri uygulayarak öğrencilerine eşit öğrenme fırsatları sunmaları gerektiğine vurgu yapmışlardır. Aynı şekilde Evans ve diğerleri (2010), öğrencilerin birbirleriyle ve öğretmenleriyle etkili etkileşim kurabilecekleri işbirlikçi bir sınıf ortamı oluşturulması gerektiğini vurgulanmaktadırlar.

Çalışmanın bir diğer bulgusu olarak ise öğretmenlerin destekleme ve yetiştirme kurslarında yazılı materyalleri (ders kitabı, soru bankası) sıkça kullanmayıp bunların yerine fazla miktarda yazı yazdırmayı tercih etmeleridir. Kaynaştırma öğrencilerinin destekleme ve yetiştirme kurslarındaki dersleri daha iyi takip etmelerini sağlayacak öğretimsel uygulamalara yeterince yer verilmediği katılımcılar tarafından belirtilmiştir. Bu açığı kapatmak için evrensel tasarımın ilkeleri dikkate alınarak öğretimde kullanılan materyaller ve etkinlikler, öğrencilerin öğrenmelerine katkı sağlayacak bir şekilde tasarlanarak onların ilgi ve ihtiyaçlarına göre düzenlenmelidir (Gül, 2014; Shaw, 2011; Tomlinson, 2005). Öğretimde içerik, öğrencilere ne öğretileceğini kapsarken süreç, öğretimin nasıl yapılması gerektiğiyle ilgili ölçütleri kapsar. Bu bağlamda kaynaştırma öğrencilerinin başarısının öğrencinin kişisel özelliklerine, gereksinimlerine ve yeterliliklerine bağlı olduğu unutulmamalıdır. Kaynaştırma öğrencileri için bireyselleştirilmiş eğitim programları uygulanmalı ve bu programlar uygulanabilir gerçeklikte olup her öğrencinin performansına ve ihtiyacına hitap etmelidir (Gül ve Vuran, 2015). Kaynaştırma öğrencilerine yönelik öğretimlerde öğretmenlerin büyük çoğunluğunun herhangi bir değişiklik yapmadığı; düzenleme yapanların ise etkinlikleri basite indirgeme, öğrencilere uygun etkinlik oluşturma ve içerik belirleme çalışmalarına odaklandıkları görülmektedir (Deniz ve Çoban, 2019).

Çift yönlü amaçlar içeren kaynaştırma uygulaması, özel gereksinimli öğrenciler ile diğer öğrencilerin aynı ortamda eğitim almalarını ve kaynaştırma öğrencilerinin yaşam kalitesini artırmayı amaçlamaktadır. Bunun yanında kaynaştırma uygulaması, kaynaştırma öğrencilerinin diğer akranlarının bu öğrencilere karşı anlayışlı olma, empati kurabilme, farklılıklara saygı duyma, hoşgörülü olma ve iş birliği kurabilme gibi davranış ve becerilerinin de kazandırılmasını 
amaçlamaktadır (Gül ve Vuran 2015). Bu çalışmanın bazı katılımcıları, kurslarda akranlarının sınıf içerisinde bazı uygun olmayan ve dikkat dağıtıcı davranışlarda bulunmasından yakınmaktadırlar. Söz konusu durum $\mathrm{M}_{3}$ katılımcısı tarafindan da doğrulanıp "Dersteyken söylemek istediklerimi söyleyemiyorum ve sormak istediklerimi soramiyorum." ve $\mathrm{M}_{2}$ kat1lımcıs 1 tarafindan "Öğretmenim bir soru sorduğunda yanlış olur diye korkuyorum ve çekiniyorum." şeklinde ifade edilmiştir. Fakat $\mathrm{M}_{1}$ rumuzlu katılımcı, normal zamanlarda yapılan derslere göre kurs derslerinde kendini daha iyi ifade ettiğini ve konu ile ilgili anlamadığ 1 yerleri öğretmenlerine sorabildiğini ifade etmiştir. Bu durumu katılımcılar, kurslarda sınıf mevcutlarının az olması ve dersleri dinleyen arkadaşlarının kursa gelmeleri ile açıklamışlardır.

Öğretmenler, kaynaştırma öğrencilerinin destekleme ve yetiştirme kurslarında akranlarıyla kurmuş olduğu 1 lımlı ortamı bir firsat olarak değerlendirmeli ve sınıf yönetimi konusunda daha dikkatli olup bu konuda sistematik çalışmalar yapmalıdırlar. Destekleme ve yetiştirme kurslarında, sınıflarında kaynaştırma öğrencisi bulunan öğretmenler yukarıda anlatılan önerileri dikkate almalıdırlar. Öğretmenler, her bir kaynaştırma öğrencisinin özel bir birey olduğu gerçeğini göz önünde bulundurmalı, kaynaştırma öğrencilerinin gereksinimlerinin de farkına varıp onları önemsemeli, etkili sınıf yönetimi tekniklerini kullanmalıdır. Bu sayede kaynaştırma eğitiminden yararlanan öğrenciler, bulundukları sınıflarda kendilerine verilen eğitimden en iyi şekilde faydalanma firsatı bulacaklardır. Ayrıca öğretmenler kaynaştırma öğrencilerinin ve diğer öğrencilerinin zaman içerisindeki akademik veya sosyal gelişimlerini düzenli olarak inceledikleri takdirde kaynaştırma eğitimine olan bakış açıları değişecek ve bu konudaki tecrübeleri de artacaktır. Bunun yanı sıra kaynaştırma eğitimi alan öğrencilerin velileri de bu gelişmelerden düzenli olarak haberdar edildiği zaman velilerin kaynaştırma eğitimine olan tutumları da olumlu yönde gelişecektir.

$\mathrm{Bu}$ çalışmada elde edilen sonuçların, hafta sonu kurslarındaki kaynaştırma uygulamalarının daha dikkatli yapılması ve kalitesinin artırılmasında büyük rol oynayacağı düşünülmektedir. Bununla birlikte kaynaştırma eğitimi alan öğrencilerin kaynaştırma uygulamalarına ilişkin görüşlerini belirlemek amacıyla nitel ve nicel veri toplama tekniklerinin bir arada kullanıldığı araştırmalara da yer verilebilir. Kursların tam merkez noktasında bulunan ve tüm uygulamanın bizzat içinde olan kaynaştırma öğrencilerinin görüşlerinin alınmasının MEB başta olmak üzere diğer tüm paydaşlara yol göstereceği düşünülmektedir.

\section{Kaynaklar}

Atlan, N. (2019). Ortaokula devam eden kaynaştırma öğrencilerinin yaşam doyumları, aile işlevleri ve kaynaştırma hakkındaki görüşlerinin incelenmesi. Yüksek lisans tezi, Hacettepe Üniversitesi, Ankara.

Batu, S. Kırcaali-İftar, G. ve Uzuner, Y. (2004). Özel gereksinimli öğrencilerin kaynaştırıldığı bir kız meslek lisesindeki öğretmenlerin kaynaştırmaya ilişkin görüş ve önerileri. Ankara Üniversitesi Ĕ̈itim Bilimleri Fakültesi Özel Eğitim Dergisi, 5, 33-50.

Batu, S. Kırcaali-İftar, G. (2005). Kaynaştırma. Ankara: Kök Yayıncılık.

Çepni, S. (2018). Araştırma ve proje çalışmalarına giriş. Trabzon: Celepler Yayıncılık.

Demir, M. K. ve Açar, S. (2011). Kaynaştırma eğitimi konusunda tecrübeli sınıf öğretmenlerinin görüşleri. Kastamonu Eğitim Dergisi, 19, 719-732.

Deniz, E. ve Çoban, A. (2019). Kaynaştırma eğitimine ilişkin öğretmen görüşleri. Elektronik Sosyal Bilimler Dergisi, 18(70), 734-761.

Denzin, N. K. and Lincoln, Y. S. (1994). The research process. In N. K. Denzin and Y. S. Lincoln (Eds.), Handbook of qualitative research, 45-81. Thousand Oaks, CA: Sage. 
Disability Discrimination Act. (1992). http://www.legislation.gov.uk/ukpga/1995/50/contents adresinden 15.02.2020 tarihinde erişildi.

Doğu, M. B. (2017). Okul öncesi eğitimde sinıflarında kaynaştırma öğrencisi bulunan öğretmenlerin karşılaştıkları sorunlar. Yüksek lisans tezi, Pamukkale Üniversitesi, Denizli.

Evans, C., Williams, J. B., King, L. and Metcalf, D. (2010). Modeling, guided instruction, and application of UDL in a rural specail educationteacher preparation program. Rural Special Education Quarterly, 29, 41-48.

Göksu, İ. ve Gülcü, A. (2016). Ortaokul ve liselerde uygulanan destekleme kurslarıyla ilgili öğretmen görüşleri. Bayburt Eğitim Fakültesi Dergisi, 11(1), 153-171.

Gül, S. O. (2014). Farklılaştırılmış öğretim ve uyarlamalar. Ufuk Üniversitesi Sosyal Bilimler Enstitüsü Dergisi, 5, 111-123.

Gül, S. O. ve Vuran, S. (2015). Normal sinıflara devam eden özel gereksinimli öğrencilerin kaynaştırma uygulamasına ilişkin görüşleri ve karşılaştıkları sorunlar. Eğitim ve Bilim, 40(180), 169-195.

Gürgür, H. (2005). Kaynaştırma uygulamasının yapıldığı ilköğretim sinıfinda işbirliği ile öğretim yaklaşımının incelenmesi. Doktora tezi, Ankara Üniversitesi, Ankara.

Kargın, T. (2004). Kaynaştırma: Tanımı, gelişimi ve ilkeleri. Ankara Üniversitesi Eğitim Bilimleri Fakültesi Özel Ĕ̈itim Dergisi, 5, 1-13.

Kargın, T. (2008). Bireyselleştirilmiş eğitim programı hazırlama ve öğretimin bireyselleştirilmesi. H. İ. Diken (Ed.), Özel eğitime gereksinimi olan ögrenciler ve özel eğitim içinde (s. 59-87). Ankara: Pegem Akademi.

Kırcaali-İftar, G. (1992). Özel eğitimde kaynaştırma. Ĕgitim ve Bilim, 16, 45-50.

Kırcaali-İftar, G. (1998). Özel gereksinimli bireyler ve özel eğitim. Eskişehir: Anadolu Üniversitesi Açıköğretim Fakültesi Yayınları.

Lewis, R. B. and Doorlag, D. H. (1999). Teaching special students in general education classrooms. Prentice Hall.

Millî Eğitim Bakanlı̆̆ı̆. (1973). Türk millî eğitim temel kanunu. https://www.mevzuat.gov.tr/MevzuatMetin/1.5.1739.pdf

MEB. (2005). İlköğretim ve orta öğretim kurumları sosyal etkinlikler yönetmeliği. https://www.mevzuat.gov.tr/Metin.Aspx?MevzuatKod=7.5.23639\&MevzuatIliski=0\&sourceX mlSearch=sosyal\%20etkinlikler adresinden 15.11.2019 tarihinde erişildi.

MEB. (2006). Özel Ĕ̈itim hizmetleri yönetmeliği. https://orgm.meb.gov.tr/www/ozel-egitimhizmetleri-yonetmeligi-yayimlandi/icerik/1089 adresinden 15.11.2019 tarihinde erişildi.

MEB. (2007). Mesleki eğitim ve öğretim sisteminin güçlendirilmesi projesi: Çocuk gelişimi ve eğitimi (Zihinsel engelliler). http://www.megep.meb.gov.tr/mte_program_modul/moduller_pdf/Zihinsel\%20Engelliler.pdf adresinden 23.12.2019 tarihinde erișildi. 
MEB. (2010). İlköğretim okullarındaki kaynaştırma uygulamalarının değerlendirilmesi. https://www.meb.gov.tr/earged/earged/ilk_kaynas_eg_uyg_deg.pdf adresinden 15.12.2019 tarihinde erişildi.

MEB. (2019). Okullarımızda neden, niçin, nasıl kaynaştırma? Yönetici, öğretmen ve aile kilavuzu. https://orgm.meb.gov.tr/alt_sayfalar/yayimlar/kaynastirma/kaynastirma.pdf adresinden 17.10.2019 tarihinde erişildi.

MEB. (2020). Özel ĕgitim hizmetleri yönetmeliği. http://orgm.meb.gov.tr/meb_iys_dosyalar/2018_07/09101900_ozel_egitim_hizmetleri_yonetme ligi_07072018.pdf adresinden 17.01.2020 tarihinde erişildi.

Miles, B. M. \& Huberman A. M., (1994). Qualitative data analysis: An expanded source book. California, USA: Sage Publications.

Orakçı, Ş. F., Aktan, O., Toraman, Ç. ve Çevik, H. (2016). The influence of gender and special education training on attitudes towards inclusion. International Journal of Instruction, 9(2), 107-122.

Pliner, S. M. and Johnson, J. R. (2004). Historical, theoretical, and foundational principles of universalinstructional design in higher education. Equity \& Excellence in Education, 37, 105113.

Prater, M. A. (2006). Teaching strategies for students with mild to moderate disabilities. New Jersey: Pearson Allyn \& Bacon.

Sarıca, R. (2018). Destekleme ve yetiştirme kurslarına yönelik öğretmen görüşleri. Millî Eğitim Dergisi, 48(221), 91-122.

Shaw, R. A. (2011). Employing universal design for learning. New Directions for Student Services, 134, 21-33.

Nartgün, Ş. S. ve Dilekçi, Ü. (2016). Eğitimi destekleme ve yetiştirme kurslarına ilişkin öğrenci ve öğretmen görüşleri. Kuram ve Uygulamada Ĕ̈itim Yönetimi Dergisi, 22(4), 537-564.

Sucuoğlu, B. ve Kargın, T. (2010). İlköğretimde kaynaştırma uygulamaları. Ankara: Kök Yayınevi.

Tomlinson, C. A. (2005). Grading and differentiation: Paradox or good practice? Theory into Practice, $44,262-269$.

Türk, N. (2011). Illköğretim okullarında uygulanan kaynaştırma eğitimi ile ilgili sosyolojik bir araştırma (Denizli örneği). Doktora tezi, Süleyman Demirel Üniversitesi, Isparta.

Ünsal, S. ve Korkmaz, F. (2016). Destekleme ve yetiştirme kurslarının işlevlerine ilişkin öğretmen görüşlerinin incelenmesi. Kahramanmaraş Sütçü İmam Üniversitesi Sosyal Bilimler Dergisi, 13(2), 87-118.

Yazıcıoğlu, T. (2018). Kaynaştırma uygulamalarının tarihsel süreci ve Türkiye'de uygulanan kaynaştırma modelleri. Nevşehir Hacı Bektaş Veli Üniversitesi Sosyal Bilimler Enstitüsü Dergisi, 8(1), 92-110.

Yıldırım, A. ve Şimşek, H. (2016). Sosyal bilimlerde nitel araştırma yöntemleri. Ankara: Seçkin Yayınları. 


\section{Extended Abstract}

\section{Introduction}

There are quite number of studies on inclusive education practice in the literature review. However, most of these studies look at the opinions of teachers, parents or peers of inclusive students. This body of research is focused on the inappropriate behaviors of the students rather than the appropriate behaviors, and punitive practices rather than reinforcement practices in reducing/eliminating the inappropriate behaviors. It was also noted that students' participation in social activities was not often encouraged and there is no consideration how peer support can be integrated in inclusive practices (Gül and Vuran, 2015). Atlan (2019) emphasized the importance of social skills and opportunities for self-expression as well as academic skills in order to increase the satisfaction and self-perception of inclusive students. The research of Deniz and Çoban (2019) concluded that most of the teachers do not have sufficient training on inclusive education, they have a limited level of collaboration, and they do not have sufficient physical opportunities regarding inclusive education. Therefore, this research has been conducted for the following reasons:

- There are limited number of studies on students who need special education and who benefit from inclusive education.

- The number of students who need inclusive education has increased recently.

- This research was designed to provide solutions to problems, particularly for managers and teachers who do not receive a qualified in-service training on how to approach inclusive students.

The research first aims to identify the problems faced by students who are in inclusive education and then aims to unearth the expectations and suggestions of the students. As a result, in the light of these expectations and suggestions, it is aimed to ensure that the inclusive students benefit from the courses in the best way and that the courses meet their needs. The findings will contribute to the literature on topics such as inclusion, and guide teachers and administrators about the issues that they should pay attention to.

\section{Method}

This research employs case study, one of the qualitative research designs. Semi-structured interview form was used, and the research was carried out with six students aged between 10 and 14 . Two participants were $6^{\text {th }}$ grade and two of them were $5^{\text {th }}$ grade students. The other two were studying at the $8^{\text {th }}$ grade. Validity and reliability studies were also carried out during the preparation of the interview form. In order to ensure internal validity, two doctoral students, an academic specialized in their fields and three psychological counselors and six graduate students were asked to provide feedback to the questions. In order to ensure the validity of the scope, the interview form was prepared by taking the opinions of the experts and later questions were presented to school psychological counselling teachers in the schools where the relevant students were located to take their opinions. Pilot research was conducted with five students who are not part of the research. Content analysis was used to analyse the data.

\section{Results}

Table 2 shows that students the Support and Training Courses in different ways. One of the students, $\mathrm{M}_{6}$, made the following statement; "When I come to the courses, I usually learn the topics better. It allows me to solve more questions by revising them. I also have the opportunity to ask my teachers about the topics I do not understand." It was emphasized that the courses provide the opportunity to compensate for the points that are not understood about the subjects during school time. In addition, $\mathrm{M}_{5}$ said: "We solve problem and we listen to what our teachers tell, we work on the tests 
distributed by our teachers or the tests on the smart board (interactive board)." He stated that these courses help them increase academic success at schools.

When Table 3 is examined, the participants are under the theme of "Reasons for participating the courses" expressed the importance of revising the subjects, working on test, asking the questions they could not to understand at school, and spending productive time. For instance, $\mathrm{M}_{1}$ stated: "The courses enable me to have an efficient time." $\mathrm{M}_{2}$ said: "We solve questions in courses. But I attend courses not only to solve questions, but also to improve my reading, writing and mathematics skills." She states that the courses are not only for central exams but also help some students to make progress. In addition, the participants stated that they attended the courses because of the revisions offered by teachers.

\section{Discussion and Conclusion}

The inclusive students who participated in this study expressed mostly positive opinions about the support and training courses, but also stated that some aspects of the courses should be improved. These courses aim at supporting students to increase their attainment in the courses in the formal education curriculum (Ministry of Education, 2014). In this regard, the aim of the Ministry of National Education is to offer these courses so that they can overlap with the curriculum at schools. However, it was determined that the aim of participation of the inclusive student is not only to prepare them for central exams, but offer them opportunities to join various activities, to spend time efficiently, to solve more questions, to compensate the working environment that they cannot find at home and to increase their academic success in school (Table 3).

As interviews show the interactive board and written course materials used in the classroom, expressions regarding the development levels of the inclusive students are ignored (Table 5). For instance, M6 stated: "Since our class population is generally more than 20 people, teachers cannot allocate one-to-one time slots for us and I have difficulty in following the lesson." $\mathrm{M}_{3}$ also stated, "I usually have to sit in the back rows in the lessons and I find it difficult to see the board, I am distracted because I cannot follow the lessons." For example, the written materials (test etc.) distributed in the lessons were not large enough for students to see and differentiate the shapes. In addition, participants think that interactive board is not used actively and that the size of the text or visuals is not appealing to them. 


\section{Ek-1: Yarı Yapılandırılmış Görüşme Formu}

- Örgün Eğitimi Destekleme ve Yetiştirme Kursları (DYK) hakkında kısaca bilgi verebilir misiniz?

- Örgün Eğitimi Destekleme ve Yetiştirme Kursları (DYK)'na katılma sebepleriniz nelerdir?

- Örgün Eğitimi Destekleme ve Yetiştirme Kursları (DYK)'nın size katkıları nelerdir?

- Örgün Eğitimi Destekleme ve Yetiştirme Kursları (DYK)'nın size göre yetersizlikleri nelerdir?

- Örgün Eğitimi Destekleme ve Yetiştirme Kursları (DYK)'nın geliştirebilmesi ve kalitesinin artırılması için neler yapılmasını istersiniz? 